\title{
Defective $\mathrm{Ca}^{2+}$ channel clustering in axon terminals disturbs excitability in motoneurons in spinal muscular atrophy
}

\author{
Sibylle Jablonka, Marcus Beck, Barbara Dorothea Lechner, Christine Mayer, and Michael Sendtner \\ Institute for Clinical Neurobiology, University of Wuerzburg, Wuerzburg D-97078, Germany
}

$\mathrm{P}$ roximal spinal muscular atrophy (SMA) is a motoneuron disease for which there is currently no effective treatment. In animal models of SMA, spinal motoneurons exhibit reduced axon elongation and growth cone size. These defects correlate with reduced $\beta$-actin messenger RNA and protein levels in distal axons. We show that survival motoneuron gene (Smn)deficient motoneurons exhibit severe defects in clustering $\mathrm{Ca}_{\mathrm{v}} 2.2$ channels in axonal growth cones. These defects also correlate with a reduced frequency of local $\mathrm{Ca}^{2+}$

\section{Introduction}

The two major forms of motoneuron disease, proximal spinal muscular atrophy (SMA) and amyotrophic lateral sclerosis, are caused by selective cell death of motoneurons. Among the mechanisms that are thought to play a central role are cellautonomous mechanisms like oxidative stress and mitochondrial dysfunction (Pasinelli and Brown, 2006), but also nonautonomous processes such as dysregulated signaling from neighboring glial cells and contacting neurons (Boillee et al., 2006; Urushitani et al., 2006). Such mechanisms have been studied in great detail for amyotrophic lateral sclerosis (Bruijn et al., 2004). In contrast, much less is known for proximal SMA, the most common form of motoneuron disease in children and young adults (Crawford and Pardo, 1996; Swash and Desai, 2000; Talbot and Davies, 2001; Iannaccone et al., 2004). This disease is caused by homozygous loss or mutations in the telomeric copy (SMN1) of the survival of motor neuron gene (SMN; Lefebvre et al., 1995) on human chromosome 5q13. Whereas the

S. Jablonka and M. Beck contributed equally to this paper. Correspondence to Michael Sendtner: Sendtner_M@klinik.uni-wuerzburg.de Abbreviations used in this paper: 8-CPT-cAMP, 8-(4-chlorophenylthio)-3', 5' cAMP; ANOVA, analysis of variance; CTX, $\omega$-conotoxin MVIIA; E, embryonic day; NM, neuromuscular junction; SMA, spinal muscular atrophy; Smn, survival motoneuron gene; STED, stimulated emission depletion; TRPC, transient receptor potential ion channel; TTX, tetrodotoxin; VGCC, voltage-gated $\mathrm{Ca}^{2+}$ channel.

The online version of this paper contains supplemental material. transients. In contrast, global spontaneous excitability measured in cell bodies and proximal axons is not reduced. Stimulation of Smn production from the transgenic SMN2 gene by cyclic adenosine monophosphate restores $\mathrm{Ca}_{\mathrm{v}} 2.2$ accumulation and excitability. This may lead to the development of new therapies for SMA that are not focused on enhancing motoneuron survival but instead investigate restoration of growth cone excitability and function.
SMN1 gene allows expression of a functionally intact fulllength protein, most of the transcripts from the SMN2 gene code for a truncated protein lacking the functionally important domains at the $\mathrm{C}$ terminus that are encoded by exon 7 (Lorson et al., 1999; Monani et al., 1999). Nevertheless, low expression of full-length Smn protein from the SMN2 gene occurs, but this is not sufficient for compensating the defect caused by SMN1 loss, thus leading to motoneuron disease in humans. In contrast to humans, mice carry only one Smn gene, and the homozygous knockout of the Smn gene in mice is lethal in early development, even before blastocysts are formed (Schrank et al., 1997).

The Smn gene is ubiquitously expressed, thus raising the question of how reduced levels of this protein lead to specific motoneuron disease. Smn plays a role in the assembly and in recycling of spliceosomal uridine-rich small nuclear RNPs (Meister et al., 2001; Pellizzoni et al., 2002). Dysfunction of such processes should lead to severe defects in all cell types. The clinical phenotype of patients with SMA indicates that low levels of SMN protein, both in the full-length and the truncated form lacking the exon 7-encoded domains, are sufficient for development, survival, and function of most types of cells, but not for motoneurons. It has therefore been hypothesized that motoneurons are more vulnerable, possibly because they are among the biggest cells in the body and their need for proper mRNA 
expression, processing, and translation is probably higher than in other cell types (Monani, 2005). This hypothesis is supported by the observation that injection of assembled small nuclear RNP complexes into early Smn-deficient zebrafish embryos can rescue defects in motoneurons (Winkler et al., 2005).

A mouse model for SMA has been generated by introducing the human SMN2 into a mouse Smn null background (Monani et al., 2000). The phenotype of these mice closely resembles that of humans. These mice develop severe paralysis within a few days after birth and normally die between postnatal day 1 and 5 . Surprisingly, the loss of motoneuron cell bodies at late stages of the disease does not exceed $20 \%$, suggesting that most motoneurons develop normally during embryogenesis and that disease becomes apparent before the majority of motoneurons are lost. Survival of spinal motoneurons that are isolated from $S m n^{-1-}$; SMN2 embryos does not differ from control motoneurons $\left(S m n^{+/+}\right.$; SMN2). However, they exhibit a specific defect in axon elongation that correlates with a defect in $\beta$-actin mRNA translocation to distal axons (Rossoll et al., 2003).

To study the underlying pathomechanism in Smn-deficient motoneurons, we have analyzed the functional consequences of Smn deficiency in growth cones. Smn-deficient motoneurons show defects in spontaneous excitability, and these defects correlate with reduced integration of voltage-gated $\mathrm{Ca}^{2+}$ channels (VGCCs) into axonal growth cones. Treatment with cAMP increases Smn levels in $\mathrm{Smn}^{-/-}$; SMN2 motoneurons and leads to restoration of the morphological and functional deficits in axons and axon terminals. These findings indicate that reduced excitability in growth cones contributes to the disease phenotype. This defect could lead to disturbances of active zones in the presynapse, causing reduced transmitter release at the motor endplate that, in turn, could contribute to motoneuron malfunction and degeneration in SMA.

\section{Results}

\section{Spontaneous excitability is reduced}

\section{in cultured Smn-deficient motoneurons}

In isolated embryonic $S m n^{-1-}$; SMN2 motoneurons, translocation of $\beta$-actin mRNA to distal axons and growth cones is disturbed (Rossoll et al., 2003). To investigate the functional consequences of Smn deficiency in axon terminals, we measured spontaneous excitability in motoneurons that were isolated from embryonic day (E) 14 of control and $\mathrm{Smn}^{-/-}$; SMN2 mutant mouse embryos, and cultured them on laminin-111. The cultured neurons were loaded with Fura-2, a $\mathrm{Ca}^{2+}$-binding fluorescent dye (Fig. 1 A, top left) and analyzed over periods of $7.5 \mathrm{~min}$ at $3,4,5$, and $7 \mathrm{~d}$ in culture (Fig. $1 \mathrm{~A}$, bottom left). In parallel to these measurements, motoneuron survival in the presence of brain-derived and ciliary neurotrophic factor $(10 \mathrm{ng} / \mathrm{ml}$ each) was determined. No difference was observed between Smn-deficient and control motoneurons (Rossoll et al., 2003). In control $\mathrm{Smn}^{+/+}$; SMN2 motoneurons that were cultured on laminin-111, spontaneous spikelike $\mathrm{Ca}^{2+}$ transients were detectable that appeared synchronized in the cell body, dendrites, axons, and axonal growth cones, thus reflecting global spontaneous depolarization as described previously for developing neurons
(Gu et al., 1994; Ciccolini et al., 2003). These transients could be blocked by $1 \mu \mathrm{M}$ tetrodotoxin (TTX), indicating that they are triggered by opening of voltage-gated $\mathrm{Na}^{+}$channels (Fig. $1 \mathrm{~A}$, top right). The addition of 0.3 and $1.0 \mu \mathrm{M} \omega$-conotoxin MVIIA (CTX) inhibited these $\mathrm{Ca}^{2+}$ transients, suggesting that N-type $\mathrm{Ca}^{2+}$ channels are responsible for the $\mathrm{Ca}^{2+}$ transients measured in these cultures (Figs. $1 \mathrm{~A}$, bottom right; and $\mathrm{S} 1 \mathrm{~A}$, available at http://www.jcb.org/cgi/content/full/200703187/DC1).

The frequency of spikelike global spontaneous $\mathrm{Ca}^{2+}$ transients within cell bodies and proximal axons of control motoneurons $\left(\mathrm{Smn}^{+/+} ; \mathrm{SMN2}\right)$ was highest on day 3, both in $\mathrm{Smn}^{-/-}$; SMN2 and control motoneurons (Fig. 1 B). It declined after day 3 both in control and $\mathrm{Smn}^{+/+}$; SMN2 motoneurons, confirming previous analyses ( $\mathrm{Gu}$ and Spitzer, 1995), perhaps because the resting potential becomes more negative in embryonic motoneurons that are cultured for longer periods (Ziskind-Conhaim, 1988). There was no difference in local transient frequency in the cell bodies and proximal axons of control and $\mathrm{Smn}{ }^{-1-}$; SMN2 motoneurons (Fig. 1 B).

We then investigated the frequency of such spikelike spontaneous transients in axons and growth cones (Fig. 1 C). At day 3 in culture, these transients were less frequent both in control and $\mathrm{Smn}^{-/-}$; SMN2 motoneurons, indicating that not every transient spreads from the cell body and proximal axon to distal axons at this stage. At day 4, spikelike transient frequency was similar in cell bodies and distal axons in control motoneurons. At the same stage, the frequency of spikelike spontaneous $\mathrm{Ca}^{2+}$ transients that reached the distal axons and growth cones was significantly reduced in $\mathrm{Smn}^{-1-}$; SMN2 motoneurons (0.39 \pm $0.11 \mathrm{~min}^{-1}$ ) in comparison to control $\mathrm{Smn}^{+/+}$; SMN2 cells $\left(0.83 \pm 0.18 \mathrm{~min}^{-1} ; \mathrm{P}<0.05\right)$. At days 5 and 7 , the frequency of these spikelike transients further declined in $\mathrm{Smn}^{-/-}$; SMN2 motoneurons (Fig. 1 C). TTX and CTX also inhibited these spontaneous $\mathrm{Ca}^{2+}$ transients on day 5 in culture (Fig. S1 A). The reduction of $\mathrm{Ca}^{2+}$ transients was $>50 \%$ at $0.3 \mu \mathrm{M}$ CTX and increased to $\sim 80 \%$ at $1 \mu \mathrm{M} \mathrm{CTX}$, indicating that influx through VGCCs is the predominant source of these fast transients of cytosolic $\mathrm{Ca}^{2+}$ (Fig. S1 A).

The time course of reduced spontaneous activity in distal axons and growth cones resembles that of axonal growth defects in these cultures. As described previously (Rossoll et al., 2003), axons in cultured $S m^{-/-}$; SMN2 motoneurons are shorter at day 5. Surprisingly, significant differences in axon elongation $(\mathrm{P}<0.05)$ are not detectable at earlier stages (Fig. 1, D, E, and J). Normally, between days 3 and 4, a doubling of axon length is observed in cultures of both control and Smn-deficient motoneurons, but the difference between Smndeficient and control cells was not significant (Fig. 1, D, F, and $\mathrm{K} ; \mathrm{P}>0.05)$. Only at days 5, 6, and 7 did reduced axon length become apparent in the $S m n^{-/-} ; S M N 2$ motoneurons (Fig. 1, D, G-I, and L-N).

These data suggest that defects in axonal $\mathrm{Ca}^{2+}$ influx precede alterations in axon growth of cultured $\mathrm{Smn}^{-1-}$; SMN2 motoneurons. However, these defects occur late, starting at E14 plus four additional days in culture $(\mathrm{E} 14+4)$, at a developmental stage when maximal axon elongation has already occurred and motor endplate differentiation progresses in vivo. 
A

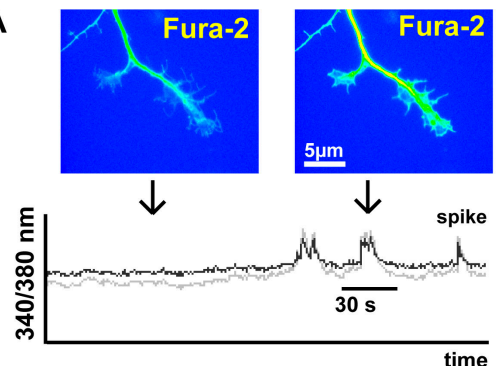

B

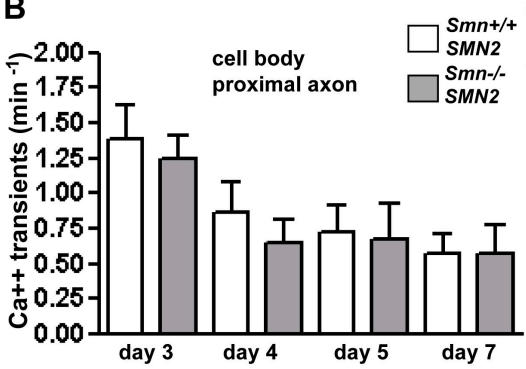

D

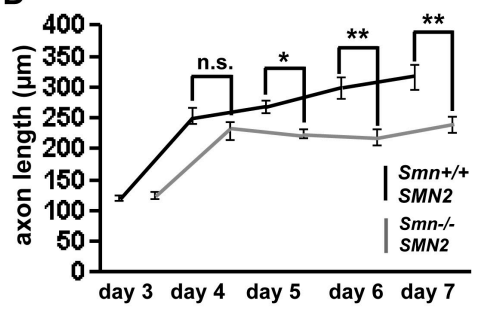

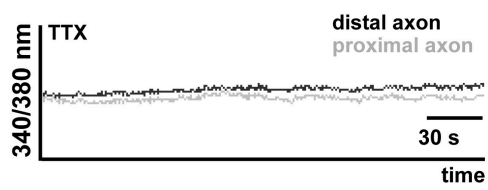

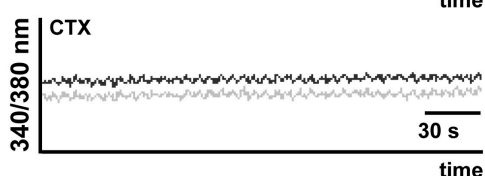

C
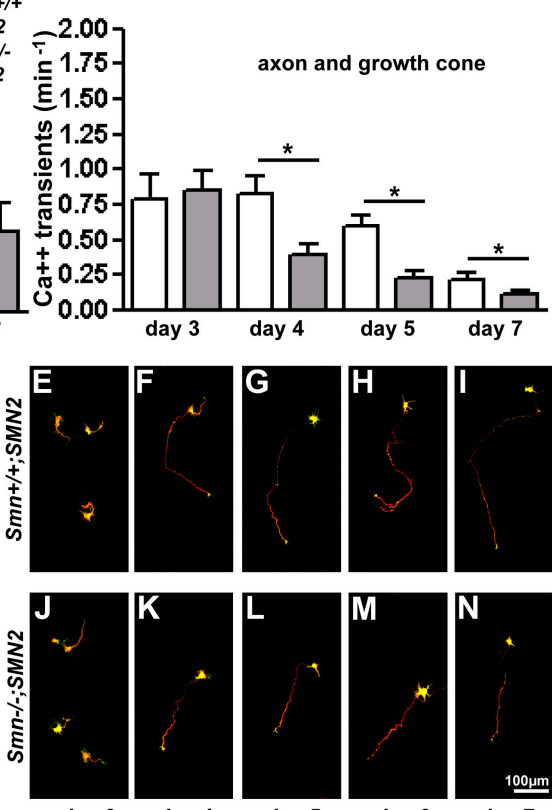

Figure 1. Reduced spontaneous $\mathrm{Ca}^{2+}$ influx into distal axons of Smn-deficient motoneurons cultured on laminin111. (A) Spontaneous $\mathrm{Ca}^{2+}$ transients in isolated motoneurons were recorded in cell bodies, proximal axons, and axonal growth cones. These spontaneous $\mathrm{Ca}^{2+}$ transients can be inhibited by addition of $1 \mu M$ TTX or CTX, respectively. ( $B$ and $C$ ) The frequency of spontaneous generalized spikelike $\mathrm{Ca}^{2+}$ transients was determined on day 3 $(n=51 / 54), 4(n=91 / 84), 5(n=74 / 84)$, and $7(n=$ 20/34) from control (Smn $\left.{ }^{+/+} ; S M N 2\right)$ and $S m n^{-/-}$; SMN2 motoneurons on laminin-1 11. No difference was observed in cell bodies and proximal axons (B) of $\mathrm{Smn}^{-1-}$; SMN2 motoneurons, but a change was detected in distal axons and growth cones $(C)$, first becoming detectable on day 4 in culture. (D and $\mathrm{E}-\mathrm{N}$ ) Axon length of cultured motoneurons from control and Smn-deficient embryos on laminin-111. Axon length was measured on day $3(n=129 / 106)$, $4(n=106 / 87), 5(n=162 / 206), 6(n=59 / 74)$, and $7(n=87 / 115)$. (D, G-I, and L-N) After day 4, the difference in axon elongation became significant. Axons of Smn-deficient motoneurons did not extend further after day 4 in comparison with control cells. Results represent the mean \pm SEM of pooled data from three independent experiments. $n$, number of motoneurons that were scored in total from control or $\mathrm{Smn}^{-1-}$; SMN2 embryos. * , $\mathrm{P}<0.05$; $* *, \mathrm{P}<0.001$, tested by one-way ANOVA.
Local $\mathrm{Ca}^{2+}$ transients in axonal growth cones are enhanced by laminin-211/221 in Smn ${ }^{-1-}$; SMNE and control motoneurons To follow the idea that axonal defects become apparent when Smn-deficient motoneurons get in contact with skeletal muscle, we investigated motoneurons on motor endplate-specific forms of laminin (laminin-211/221). Previous papers have shown that neurite growth of motoneurons is reduced on this substrate (Porter et al., 1995; Greka et al., 2003). Furthermore, it has been shown that the $\beta 2$ chain in laminin-221 interacts with the pore-forming $\left(\mathrm{Ca}_{\mathrm{v}}\right)$ subunit of the N-type VGCC $\left(\mathrm{Ca}_{\mathrm{v}} 2.2\right.$; Nishimune et al., 2004). Thus, presynaptic differentiation appears mediated through the direct interaction of laminin-221 with $\mathrm{Ca}_{\mathrm{v}} 2.2$ channels. We therefore measured $\mathrm{Ca}^{2+}$ transients that only occurred in growth cones (Fig. 2 A). Such local transients have been identified in many types of developing neurons, including motoneurons, and some of these transients are caused by $\mathrm{Ca}^{2+}$ influx through other channels than VGCCs (Spitzer, 2002). Evidence has been presented that the transient receptor potential ion channel 5 (TRPC5) is a channel that can regulate neurite growth and growth cone morphology, at least in hippocampal neurons (Greka et al., 2003). Fast $\mathrm{Ca}^{2+}$ transients, which only occur in growth cones but not in proximal axons and cell bodies, were barely detectable on laminin-111, neither in $\mathrm{Smn}^{-/-}$; SMN2 nor in control motoneurons at day 5 in culture (Fig. 2 B).
They were much more frequent on laminin-211/221, both in control $\left(0.22 \pm 0.06 \mathrm{~min}^{-1}\right.$ on laminin-211/221 vs. $0.04 \pm 0.03 \mathrm{~min}^{-1}$ on laminin-111) and $S m n^{--}$; SMN2 motoneurons $(0.07 \pm 0.03$ $\min ^{-1}$ on laminin-211/221 vs. $0.02 \pm 0.01 \mathrm{~min}^{-1}$ on laminin-111; Fig. 2 B). In control cultures, $\sim 50 \%$ of these local transients in growth cones could be blocked with CTX (Fig. S1, B and C), indicating that VGCCs are also responsible for some but not all fast local transients in growth cones of isolated embryonic mouse motoneurons. The frequency of these local $\mathrm{Ca}^{2+}$ transients was significantly lower in $\mathrm{Smn}^{-1-}$; SMN2 motoneurons on laminin-211/221 at day 5 in culture (Fig. 2 B, $\mathrm{P}<0.05$ ).

\section{Cav2.2 is reduced in axonal growth cones of $\mathrm{Smnn}^{-1-}$; SMNe motoneurons}

In embryonic motoneurons, the N-type VGCCs are predominantly expressed (Urbano et al., 2002; Spafford and Zamponi, 2003). These channels are located in axon terminals of motoneurons where they act as receptors for motor endplate-specific forms of laminin (Nishimune et al., 2004). Because embryonic cultured $\mathrm{Smn}^{-/-}$; SMN2 motoneurons showed reduced spontaneous $\mathrm{Ca}^{2+}$ transients in growth cones, we investigated expression and cellular distribution of $\mathrm{Ca}_{\mathrm{v}} 2.2$ in control and Smn-deficient motoneurons (Fig. 3, A-I and M-O) using polyclonal antibodies against the $\alpha 2$ chain of this channel. The $\mathrm{Ca}_{\mathrm{v}} 2.2$ signal intensity was quantified as arbitrary units based on quantum levels per 

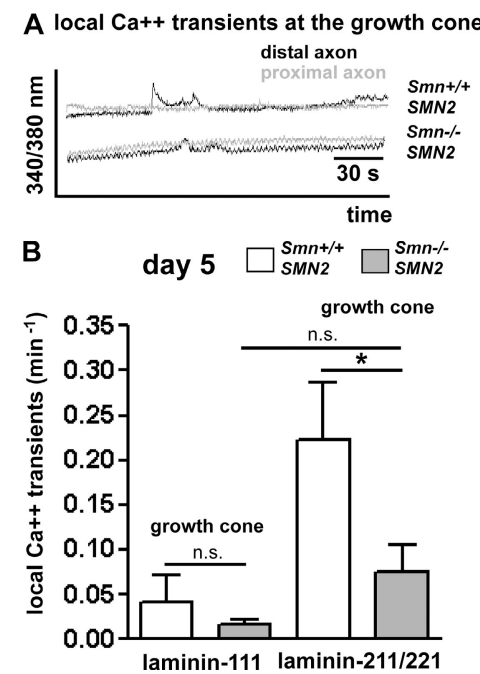

Figure 2. Decreased frequency of local spontaneous $\mathrm{Ca}^{2+}$ transients in growth cones of $\mathrm{Smn}^{-/-}$; SMN2 motoneurons on laminin-211/221. (A) Local $\mathrm{Ca}^{2+}$ transients in growth cones (black) were more frequent in $\mathrm{Smn}^{+/+}$; SMN2 motoneurons than in $\mathrm{Smn}^{-/-}$; SMN2 motoneurons cultured for $5 \mathrm{~d}$. (B) The frequency of local spontaneous $\mathrm{Ca}^{2+}$ transients was significantly higher both for control $(n=34)$ and Smn-deficient motoneurons $(n=39)$ on laminin-211/221 in comparison with laminin-111 $(n=35 / 42)$. Despite the higher frequency on laminin-211/221, local transients on laminin$211 / 221$ were significantly less frequent in Smn-deficient motoneurons in comparison with controls. Results represent the mean \pm SEM of pooled data from three independent experiments. $n$, number of motoneurons that were scored in total from control or $\mathrm{Smn}^{-1-}$; SMN2 embryos. * $\mathrm{P}<0.05$ tested by one-way ANOVA.

pixel per area in cell body, proximal axon, and growth cones. A significantly reduced signal intensity $(\mathrm{P}<0.001)$ was found in growth cones of Smn-deficient motoneurons $(8.7 \pm 1.1)$ versus controls (21.9 \pm 2.1 ; Fig. 3, C-E). Applying a fixation protocol without detergent and shortened exposure to 4\% PFA to increase the staining intensity of cell surface-exposed versus intracellular $\mathrm{Ca}_{\mathrm{v}} 2.2$, showed this channel to be highly concentrated in protrusions of control growth cones (Fig. 3, F and G) but not in $\mathrm{Smn}^{-1-}$; SMN2 growth cones (Fig. 3, H and I). Furthermore, $\mathrm{Ca}_{\mathrm{v}} 2.2$ channels colocalize with the active zone protein Piccolo, indicating that clusters of $\mathrm{Ca}_{v} 2.2$ have formed active zone-like structures in the growth cone protrusions in control motoneurons (Fig. S2, A, C, E, and G, available at http://www.jcb.org/cgi/content/full/200703187/DC1). The colocalization of $\mathrm{Ca}_{v} 2.2$ with Piccolo was highly reduced in Smndeficient growth cones (Fig. S2, B, D, F, and H). In control motoneurons, these active zone-like structures cover $\sim 20 \%$ of the whole growth cone area. In Smn-deficient motoneurons $<5 \%$ of the active zone-like structures are detectable (Fig. S2 I). These structures are only found in protrusions but not the core or the proximal parts of growth cones and axons (Fig. S2, J-L). In contrast to growth cones, the signal intensity in cell bodies of $\mathrm{Smn}^{+/+}$; SMN2 and $\mathrm{Smn}^{-/-}$; SMN2 motoneurons was not different (Fig. 3, A, B, and E).

To analyze whether the reduced $\mathrm{Ca}_{\mathrm{v}} 2.2$ expression in distal axons is caused by disturbed subcellular distribution of the corresponding mRNA, in situ hybridization was performed. This experiment did not reveal any difference in cellular distribution or rough differences in expression levels between control and Smn-deficient motoneurons (Fig. 3, J and K). The specificity of the in situ hybridization was controlled with a $\mathrm{Ca}_{\mathrm{v}} 2.2$ sense probe (Fig. $3 \mathrm{~L}$ ).

We also applied stimulated emission depletion (STED) fluorescence microscopy (Dyba and Hell, 2003; Kittel et al., 2006; Willig et al., 2006) to investigate whether the reduced accumulation of $\mathrm{Ca}_{\mathrm{v}} 2.2$ reflects a defect in cluster formation of this channel. This method enhances the resolution of confocal microscopy in the xy axis, so that structures $<200 \mathrm{~nm}$ that normally cannot be resolved by classical light microscopy become detectable. Intracellular vesicles containing $\mathrm{Ca}_{\mathrm{v}} 2.2$ channels are much smaller than the $\mathrm{Ca}_{\mathrm{v}} 2.2$ clusters that form on the cell surface. When we compared the size of the $\mathrm{Ca}_{\mathrm{v}} 2.2$ immunoreactive areas in control and $\mathrm{Smn}^{-1-}$; SMN2 growth cones, it became apparent that in Smn-deficient growth cones the relative density of large clusters covering an area of at least $0.01 \mu \mathrm{m}^{2}$ versus small vesicles is reduced compared with control growth cones (Fig. 3, $\mathrm{M}-\mathrm{O}$ ). Collectively, these data suggest that a defect in $\mathrm{Ca}_{\mathrm{v}} 2.2$ transfer into the cell membrane and active zone-like structures in Smn-deficient growth cones is responsible for reduced frequency of $\mathrm{Ca}^{2+}$ transients.

\section{Inhibition of axon elongation}

by laminin-211/221 does not occur

in Smn ${ }^{-1-}$; SMNE motoneurons

In parallel to $\mathrm{Ca}^{2+}$ transients, we also analyzed axon elongation on laminin-211/221. Mean axon length of control motoneurons was $264.1 \pm 11.2 \mu \mathrm{m}$ on laminin-211/221 in comparison to $335.2 \pm 19.0 \mu \mathrm{m}$ on laminin-111 after $7 \mathrm{~d}$ in culture (Fig. 4, A, B, and D). Surprisingly, Smn-deficient motoneurons did not show such a reduction of axon growth on laminin-211/221. In contrast, they exhibited a slight but significant $(\mathrm{P}<0.05)$ increase in axon extension $(309.2 \pm 12.5 \mu \mathrm{m})$ in comparison with control motoneurons $(259.6 \pm 10.3 \mu \mathrm{m})$ on laminin-211/221 (Fig. 4, A, C, and E).

We then measured the size of axonal growth cones because previous studies have shown that the deficit in axonal $\beta$-actin mRNA and protein correlates with reduced axon elongation and growth cone size in $\mathrm{Smn}^{-1-}$; SMN2 motoneurons that were cultured on laminin-111 (Rossoll et al., 2003). The growth cone area of Smn-deficient motoneurons on laminin-211/221 did not differ from the area on laminin-111 (Fig. 4, F, H, and J). On both substrates, growth cones of $\mathrm{Smn}^{-/-}$; SMN2 motoneurons were smaller than those of $\mathrm{Smn}^{+/+}$; SMN2 motoneurons (Fig. 4, F-J).

\section{Blockade of $\mathbf{N}$-type $\mathrm{Ca}^{2+}$ channels does not reduce axon growth in Smn-deficient motoneurons}

Inhibition of $\mathrm{Ca}_{v} 2.2$ with CTX blocks global $\mathrm{Ca}^{2+}$ transients in control motoneurons by $>80 \%$ (Fig. S1 A). In addition, local transients that only occur in axonal growth cones are reduced by $>50 \%$, both at 1 and $0.3 \mu \mathrm{M} \mathrm{CTX}$, which is considered to be highly specific for N-type VGCCs (Fig. S1, A-C). Interestingly, the reduction of local transients in growth cones is smaller, thus confirming earlier observations with Xenopus laevis motoneurons that other $\mathrm{Ca}^{2+}$ channels contribute to rapid local $\mathrm{Ca}^{2+}$ 


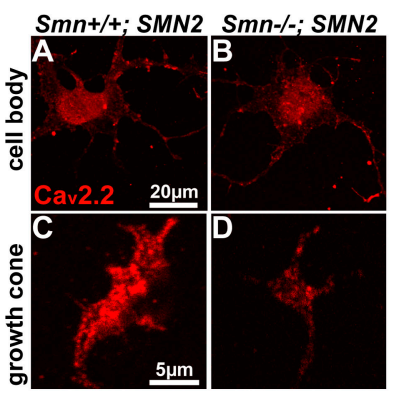

\section{E Cav2.2 signal intensity}

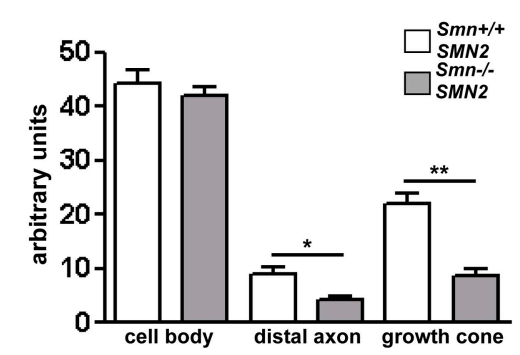

Membrane localization of Cav2.2
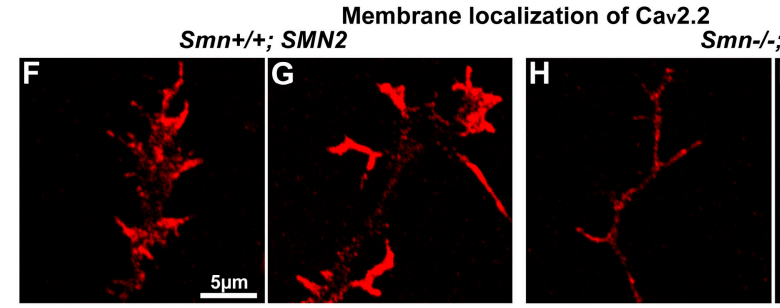

$S M N 2$
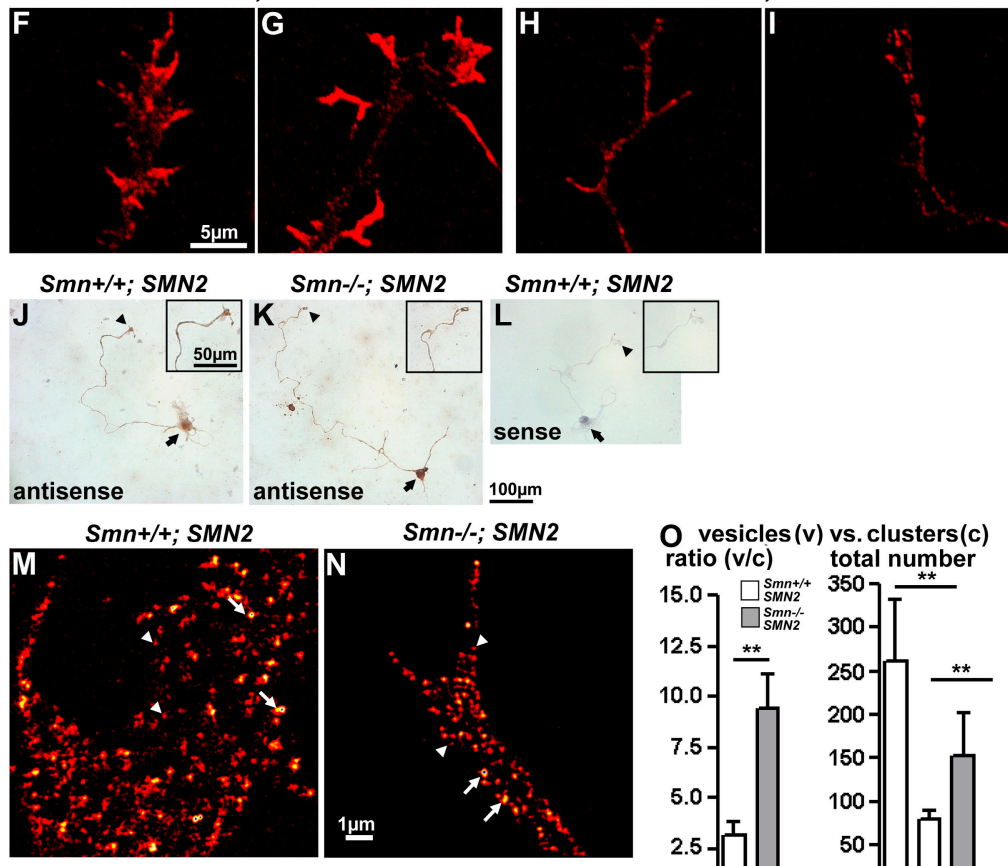

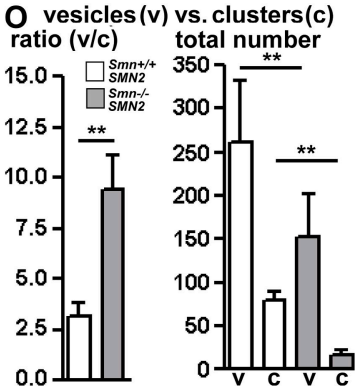

Figure 3. Expression and cellular distribution of $\mathrm{Ca}_{\mathrm{v}} 2.2$ protein and mRNA in primary motoneurons of $\mathrm{Smn}^{-1-}$; SMN2 and $\mathrm{Smn}^{+/+}$; SMN2 embryos. (A-E) Distribution and quantitative analysis of $\mathrm{Ca}_{\mathrm{v}} 2.2$ protein in 7-d-old primary motoneurons of $\mathrm{Smn}^{-1-}$; SMN2 and $\mathrm{Smn}^{+/+}$; SMN2 embryos on laminin-211/221. The signal intensity for $\mathrm{Ca}_{\mathrm{v}} 2.2$ protein in the cell body of $\mathrm{Smn}^{-1-}$; SMN2 motoneurons ( $\mathrm{A}$ and $\mathrm{E} ; n=$ $30)$ is not reduced in comparison to control cells (B and $E$; $n=30$ ). In contrast, the signal intensity for $\mathrm{Ca}_{\mathrm{v}} 2.2$ is lower in axonal growth cones of $\mathrm{Smn}^{-1-}$; SMN2 motoneurons (D and E; $n=30)$ in comparison to controls (C and $E ; n=30)$. (F-I) $\mathrm{Ca}_{\mathrm{v}} 2.2$ immunoreactivity is highly enriched in growth cone protrusions in control motoneurons ( $F$ and $G ; n=25$ ) but not in Smn-deficient motoneurons $(\mathrm{H}$ and $\mathrm{I} ; n=23)$ that were fixed for short time periods and immunostained in the absence of detergent to enrich staining of extracellular versus intracellular $\mathrm{Ca}_{\mathrm{v}} 2.2$. ( $\mathrm{J}$ and $\mathrm{K}$ ) Differences in $\mathrm{Ca}_{\mathrm{v}} 2.2$ mRNA distribution are not detected in cell bodies (arrows) and growth cones (arrowheads and insets) of motoneurons from $\mathrm{Smn}^{-1}$; SMN2 embryos $(n=35)$ in comparison to controls $(n=32)$. (L) The specificity of the antisense probe was tested with a sense $\mathrm{Ca}_{\mathrm{v}} 2.2 \mathrm{cDNA}$ probe. ( $\mathrm{M}$ and $\mathrm{N}$ ) For high-resolution microscopy, STED microscopy was applied to reduce the focal spot area by one order of magnitude, thus allowing the distinction of small vesicle-like structures (arrowheads) from larger areas that probably (as discussed in the text) reflect clusters at the cell surface (arrows). (O) The ratio between vesicles and clusters is increased in Smn-deficient motoneurons, caused by a significant reduction of the cluster-like structures in $\mathrm{Smn}^{-1-}$. SMN2 growth cones ( $\mathrm{N}$ and $\mathrm{O}$ ) in contrast to growth cones of control motoneurons ( $\mathrm{M}$ and $\mathrm{O}$ ). Results represent the mean \pm SEM of pooled data from three independent experiments. $n$, number of motoneurons that were scored in total from control or $\mathrm{Smn}^{-1-}$; SMN2 embryos. ${ }^{*}, \mathrm{P}<0.05 ;{ }^{*}{ }^{*}, \mathrm{P}<0.001$, tested by one-way ANOVA and $t$ test, respectively. transients in growth cones (Spitzer et al., 2000). To determine the role of classical VGCCs for axon growth, we tested whether specific blockade of $\mathrm{Ca}_{\mathrm{v}} 2.2$ with CTX affects axon growth of motoneurons in vitro. CTX was applied at $1 \mu \mathrm{M}$ and a lower concentration $(0.3 \mu \mathrm{M})$ that is considered highly specific for N-type VGCCs (Figs. 5 and S1). After $7 \mathrm{~d}$ in culture, motoneurons grown on laminin-111 or laminin-211/221 were fixed and stained against tau and microtubule-associated protein 2 to distinguish dendrites and axons (Rossoll et al., 2003). 1 MM CTX specifically reduces axon growth of control motoneurons on laminin-111 (335.2 \pm 19.0 vs. $240.7 \pm 8.5 \mu \mathrm{m})$, whereas $0.3 \mu \mathrm{M}$ CTX was less efficient $(335.2 \pm 19.0$ vs. $288.2 \pm 11.8 \mu \mathrm{m}$; Fig. $5 \mathrm{~A})$. Axon growth of Smn-deficient neurons on laminin-111 (233.4 \pm $13.8 \mu \mathrm{m})$, which was already disturbed, was not further reduced both by 1 and $0.3 \mu \mathrm{M}$ CTX (Fig. $5 \mathrm{~A}$ ).

We then investigated the effect of 0.3 and $1 \mu \mathrm{M}$ CTX on motoneurons grown on laminin-211/221. Inhibition of $\mathrm{Ca}_{\mathrm{v}} 2.2$ with CTX led to an increase in axon growth in control motoneurons (Fig. 5 B) at both concentrations. Axon elongation reached comparable levels to those seen in motoneurons on laminin-111 (Fig. 5 A). Smn-deficient motoneurons did not show increased axon elongation after 0.3 and $1 \mu \mathrm{M}$ CTX treatments (Fig. 5 B), indicating that the response of axonal growth to blockade of
$\mathrm{N}$-type $\mathrm{Ca}^{2+}$ channels is lacking in Smn-deficient motoneurons. Low concentrations $(0.3 \mu \mathrm{M})$ of CTX showed similar effects as $1 \mu$ M CTX on laminin-211/221, thus providing an argument for the specificity of the effect for $\mathrm{Ca}_{\mathrm{v}} 2.2$ channels.

In other types of neurons, TRPC 3 and 6 have been shown to mediate $\mathrm{Ca}^{2+}$ fluxes that modulate axon guidance and neuronal survival in response to brain-derived neurotrophic factor ( $\mathrm{Li}$ et al., 2005; Jia et al., 2007). In addition, TRPC5 activation promotes axon guidance and neurite growth in hippocampal neurons (Greka et al., 2003). Therefore, the possibility exists that TRPCs are also involved in the pathological alterations observed in Smn-deficient motoneurons. Among these candidates, TRPC5 is highly expressed in embryonic motoneurons. TRPC6 is also found but at relatively lower levels, whereas TRPC3 is barely detectable (unpublished data). When we analyzed the distribution of TRPC5 and 6 immunoreactivity in growth cones of control and Smn-deficient motoneurons, no difference was observed, both with respect to subcellular distribution (Fig. S3, A-D, available at http://www.jcb.org/cgi/content/full/200703187/DC1) and signal intensity (Fig. S3, E and F). This led us to conclude that alteration in $\mathrm{Ca}_{\mathrm{v}} 2.2$ distribution is responsible for the differences in $\mathrm{Ca}^{2+}$ transients observed in growth cones of Smndeficient motoneurons. 
A

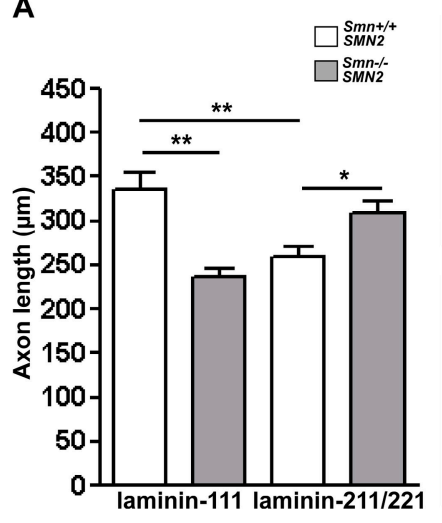

Laminin-111
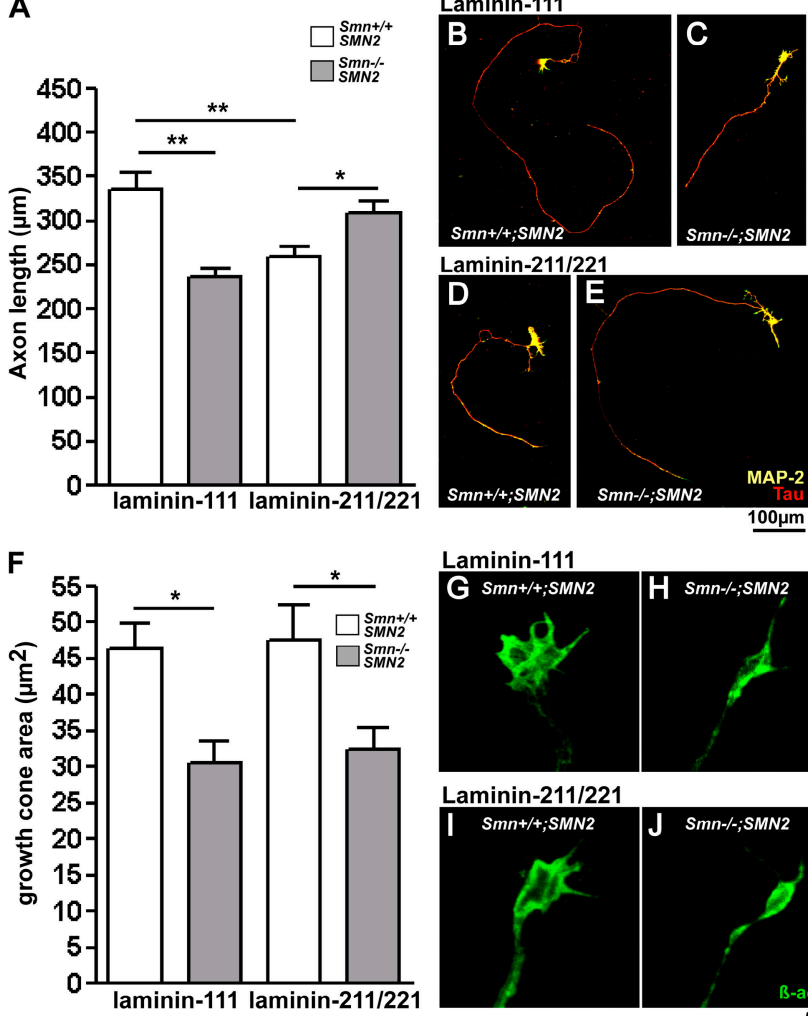

Laminin-111

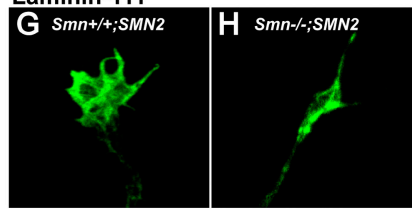

Laminin-211/221

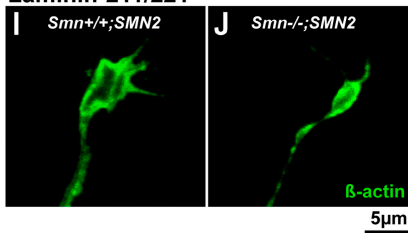

Figure 4. Axon growth and growth cone morphology of Smn ${ }^{-/-}$; SMN2 motoneurons on laminin-211/221. (A-E) Axon length of control and Smndeficient motoneurons on laminin-1 11 and laminin-211/221 after $7 d$ in culture. (A-C) Axons of $\mathrm{Smn}^{-/-}$; SMN2 motoneurons $(n=210)$ are shorter than those of control motoneurons $(n=93)$ on laminin-1 11. (A, D, and $E$ ) In contrast, axons of $\mathrm{Smn}^{-1-}$; SMN2 motoneurons $(n=141)$ extend significantly longer on laminin-211/221. (F-J) Growth cones of Smn-deficient motoneurons are significantly smaller both on laminin-1 $11(\mathrm{~F}-\mathrm{H} ; n=32)$ and laminin-21 1/221 (F, l, and J; $n=30)$. Results represent the mean \pm SEM of pooled data from three independent experiments. $n$, number of motoneurons that were scored in total from control or $\mathrm{Smn}^{-/-} ; \mathrm{SMN} 2$ embryos. $*, \mathrm{P}<0.05 ; * *, \mathrm{P}<0.001$, tested by one-way ANOVA.

\section{8-(4-chlorophenylthio)-3',5' CAMP (8-CPT-cAMP) enhances SMN protein in $\mathrm{Smn}^{-1-}$; SMN2 motoneurons and restores morphological and functional alterations in axons}

We further tested whether cAMP, which has previously been described to enhance the frequency of spontaneous $\mathrm{Ca}^{2+}$ transients in developing Xenopus motoneurons (Gorbunova and Spitzer, 2002), could enhance the frequency of $\mathrm{Ca}^{2+}$ transients in growth cones of control and Smn-deficient mouse motoneurons. Surprisingly, there was only little effect $(\mathrm{P}>0.05)$ in cultured control motoneurons (Fig. 6 A). In contrast, $\mathrm{Smn}^{-1-}$; $S M N 2$ axonal growth cones react with a more than twofold increase in the frequency of $\mathrm{Ca}^{2+}$ transients on day 5 in axon terminals after treatment with $100 \mu \mathrm{M} 8$ 8-CPT-cAMP. To test whether 8-CPT-cAMP has a direct effect on $\mathrm{Ca}^{2+}$ transients, we added CTX together with 8-CPT-cAMP (Fig. S1, C and D). Enhanced cAMP does not rescue the reduction of $\mathrm{Ca}^{2+}$ transients that is caused by CTX (Fig. S1 C), indicating that there are no CTX-insensitive channels present that open in response to
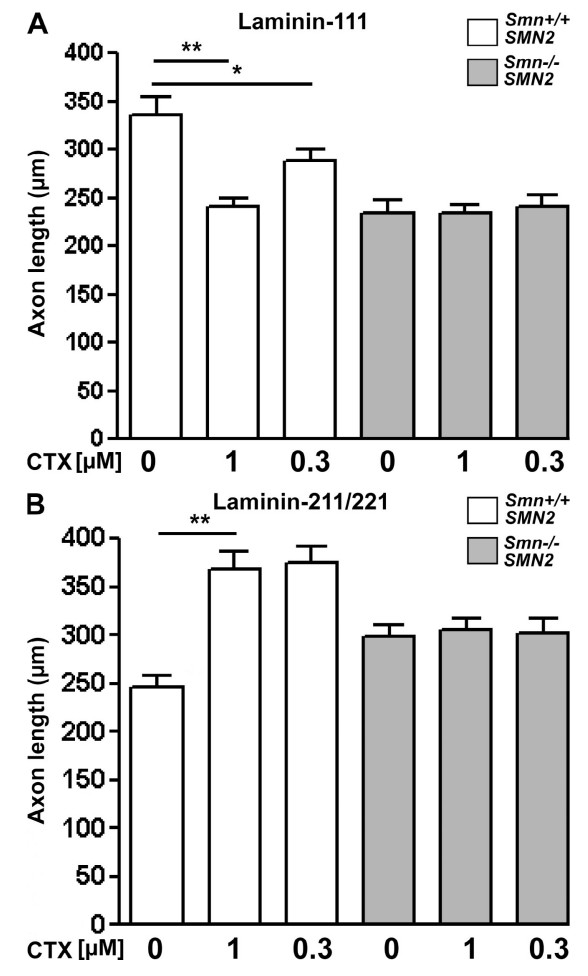

Figure 5. Axon growth after blockade of $\mathrm{Ca}_{\mathrm{v}}$ 2.2. with CTX in $\mathrm{Smn}^{-1-}$; SMN2 and control motoneurons. (A and B) Axon length of 7-d-old isolated motoneurons from control and Smn-deficient embryos that were grown on laminin-111 (A) and laminin-211/221 (B) treated with 1 and $0.3 \mu M$ CTX, respectively. (A) On laminin-111, control neurons responded to 1 ( $n=162$ ) and $0.3 \mu M$ CTX $(n=186)$ with reduced axon growth, whereas Smndeficient cells were unaffected in the presence of both concentrations $(n=151$ for $1 \mu M$ and $n=82$ for $0.3 \mu M$ CTX). (B) On laminin-211/221, CTXtreatment, both with 1 and $0.3 \mu \mathrm{M}$, increases axon extension in control motoneurons ( $n=99$ for $1 \mu M$ and $n=59$ for $0.3 \mu M$ CTX) but not in Smndeficient neurons ( $n=102$ for $1 \mu M$ and $n=82$ for $0.3 \mu M$ CTX). Results represent the mean \pm SEM of pooled data from three independent experiments. $n$, number of motoneurons that were scored in total from control or $\mathrm{Smn}^{-1}$; SMN2 embryos. ${ }^{*}, \mathrm{P}<0.05 ;{ }^{*}{ }^{*}, \mathrm{P}<0.001$, tested by one-way ANOVA.

8-CPT-cAMP. When we treated $\mathrm{Smn}^{-/-}$; SMN2 motoneurons with CTX, there was little further reduction of local $\mathrm{Ca}^{2+}$ transients, but treatment with 8-CPT-cAMP increases $\mathrm{Ca}^{2+}$ transient frequency (Fig. S1 D). This improvement only occurs in $\mathrm{Smn}^{-/-}$; SMN2 but not in control motoneurons, leading to similar levels of $\mathrm{Ca}^{2+}$ transients than those observed with CTX and 8-CPTcAMP in control motoneurons (Fig. S1 C). The difference between control and Smn-deficient motoneurons suggests that the improvement is not caused by the opening of VGCCs that were blocked by CTX treatment, because this increase in $\mathrm{Ca}^{2+}$ transients should then occur in both groups and not only in $\mathrm{Smn}^{-/-}$; SMN2 motoneurons.

We then analyzed whether this increase of $\mathrm{Ca}^{2+}$ transients in 8-CPT-cAMP-treated Smn-deficient motoneurons correlates with increased $\mathrm{Ca}_{v} 2.2$ expression in Smn-deficient growth cones. Both the signal intensity of the $\mathrm{Ca}_{\mathrm{v}} 2.2$ staining (Fig. 6, B-D, F, G, I, and J) and $\beta$-actin in growth cones (Fig. 6, B, C, E, F, H, I, and K) was increased to almost normalized levels by this treatment.

The Smn promoter region contains a CreII-binding element (Majumder et al., 2004) that mediates cAMP effects on increased SMN2 transcription in mouse hepatocytes. We therefore 


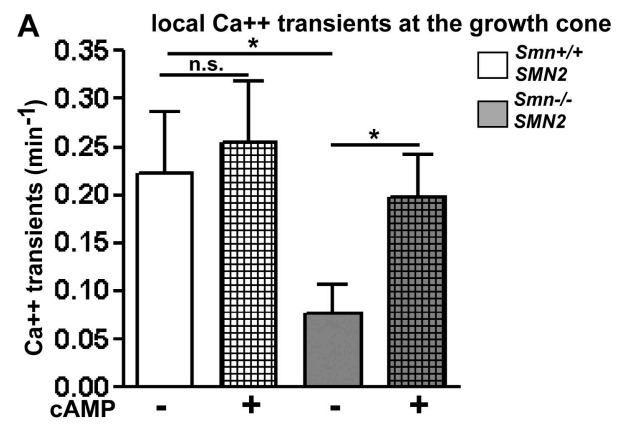

B Cav2.2 signal intensity B-actin signal intensity

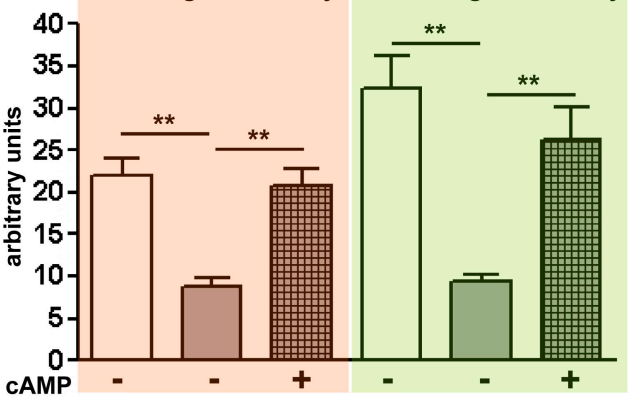

Smn+/+;SMN2
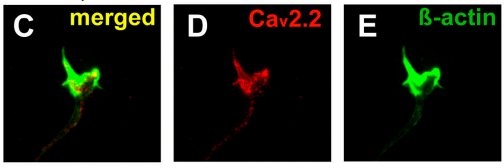

Smn-/-;SMN2 without cAMP
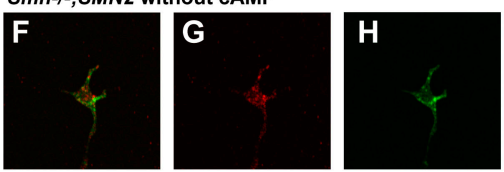

Smn-/-;SMN2 with 100uM CAMP
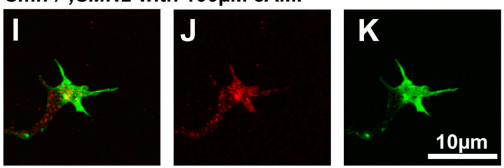

Figure 6. 8-CPT-cAMP treatment restores local $\mathrm{Ca}^{2+}$ transients and $\mathrm{N}$-type $\mathrm{Ca}^{2+}$ channel $\left(\mathrm{Ca}_{\mathrm{v}} 2.2\right)$ immunoreactivity in axonal growth cones of $\mathrm{Smn}^{-1-}$; SMN2 motoneurons. (A) Local $\mathrm{Ca}^{2+}$ transients in growth cones of Smndeficient motoneurons $(n=30)$ that were cultured for $5 \mathrm{~d}$ on laminin-2 $11 / 221$ are restored by 8-CPT-cAMP in comparison with controls $(n=30)$. (B) Quantitative analysis of immunoreactivity for $\mathrm{Ca}_{\mathrm{v}} 2.2$ and $\beta$-actin in 5-d-old control (white bar; $n=30$ ), $\mathrm{Smn}^{-/-}$; SMN2 (gray bar; $n=30$ ), and 8-CPT-cAMPtreated $\mathrm{Smn}^{-1-}$; SMN2 motoneurons (checkered bar; $n=30$ ) cultured on laminin-21 1/221. (C-E) In control motoneurons, $\mathrm{Ca}_{\mathrm{v}} 2.2$ (C and $\left.\mathrm{D}\right)$ and $\beta$-actin (E) are enriched in axonal growth cones. (F-H) Smn-deficient motoneurons exhibit reduced $\mathrm{Ca}_{\mathrm{v}} 2.2$ and $\beta$-actin accumulation in comparison to controls. ( $B$ [checkered bar] and I-K) The reduction of signal intensity for $\mathrm{Ca}_{\mathrm{v}} 2.2$ and $\beta$-actin is restored by $100 \mu \mathrm{M}$ 8-CPT-cAMP. Results represent the mean \pm SEM of pooled data from three independent experiments. $n$, number of motoneurons that were scored in total from control or Smn ${ }^{-1-}$; SMN2 embryos. ${ }^{*}, \mathrm{P}<0.05 ;{ }^{*}$ *, $\mathrm{P}<0.001$, tested by one-way ANOVA.

tested whether cAMP up-regulates Smn expression and thus restores the morphological and functional alterations in Smndeficient motoneurons. For this purpose we analyzed Smn protein levels and distribution in cultured embryonic motoneurons. Because the number of motoneurons that can be isolated from one Smn-deficient embryo is not sufficient for quantitative RT-PCR or Western blot analysis, we prepared protein and RNA extracts from cultures of E11.5 forebrain neuronal precursor cells from
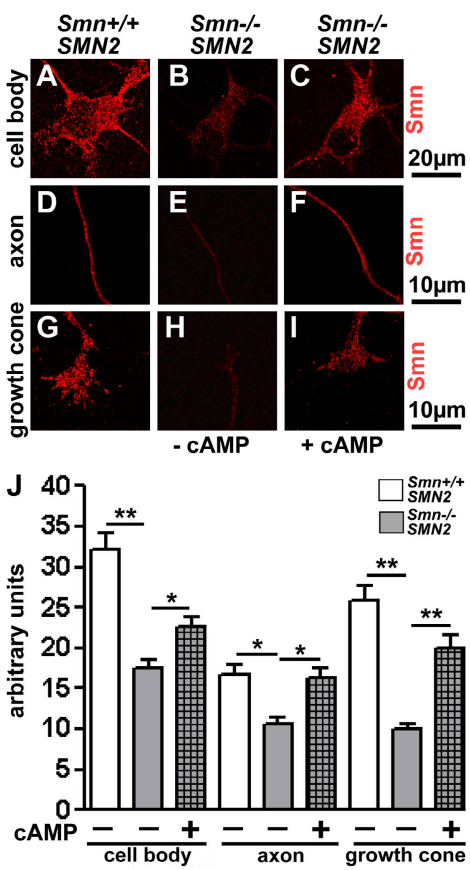

Figure 7. Smn protein distribution in control and $S m n^{-/-}$; SMN2 motoneurons after treatment with 8-CPT-cAMP. (A-I) Distribution of $S m n$ protein in cell body (A-C), axon (D-F), and growth cones (G-I) of $\mathrm{Smn}^{+/+}$; SMN2 (A, D, and G), Smn ${ }^{-1-}$; SMN2 (B, E, and H), and 8-CPT-cAMP-treated $\mathrm{Smn}^{-1-}$; SMN2 (C, F, and I) primary motoneurons cultured for $7 \mathrm{~d}$ on laminin-2 $11 / 221$. $100 \mu$ M 8-CPT-cAMP increases Smn immunoreactivity in cell bodies, axons, and growth cones of $\mathrm{Smn}^{-1-}$; SMN2 motoneurons $(n=20$ for controls, $n=20$ for $\mathrm{Smn}^{-1-}$; SMN2, and $n=20$ for $\mathrm{Smn}^{-/-}$; SMN2 treated with $100 \mu$ M 8-CPT-cAMP). (J) Quantitative analysis of Smn immunoreactivity revealed a significant $S m n$ increase in 8-CPT-cAMP-treated motoneurons (checkered bars) in comparison to untreated $\mathrm{Smn}^{-1-}$; SMN2 motoneurons. Results represent the mean \pm SEM of pooled data from three independent experiments. $n$, number of motoneurons that were scored in total from control, Smn ${ }^{-1-}$; SMN2, or Smn ${ }^{-1-}$; SMN2 embryos treated with $100 \mu \mathrm{M}$ 8-CPT-cAMP. * ${ }^{*} \mathrm{P}<0.05$; ${ }^{*}{ }^{*}, \mathrm{P}<0.001$, tested by one-way ANOVA.

control and Smn-deficient mice. $100 \mu \mathrm{M}$ 8-CPT-cAMP increased SMN2 mRNA (Fig. S4, A and B, available at http://www.jcb .org/cgi/content/full/jcb.200703187/DC1) and protein levels by $\sim 40-100 \%$ (Fig. S4 C) in these cells.

Primary motoneurons from $\mathrm{Smn}^{-/-}$; SMN2 and $\mathrm{Smn}^{+/+}$; SMN2 embryos were treated with $100 \mu \mathrm{M}$ 8-CPT-cAMP. Both in cell bodies, axons, and axonal growth cones, Smn-specific fluorescence signal intensity was enhanced in Smn-deficient neurons but not fully restored to control levels (Fig. 7, A-J). The reduction of growth cone size is the most prominent pathological feature in cultured $\mathrm{Smn}^{-/-}$; SMN2 motoneurons (Rossoll et al., 2003). 8-CPT-cAMP treatment normalized growth cone size in $\mathrm{Smn}^{-1-}$; SMN2 motoneurons to control levels and CTX did not abolish the rescue effect, indicating that it does not involve enhanced $\mathrm{Ca}^{2+}$ transients (Fig. 8, A-E). We then investigated whether this effect is caused by a normalization of local $\beta$-actin levels in distal axons. The ratio of distal to proximal $\beta$-actin protein levels is reduced in $\mathrm{Smn}^{-1-}$; SMN2 motoneurons (Rossoll et al., 2003), and this ratio was normalized by 8-CPT-cAMP (Fig. $8 \mathrm{~F})$. The altered $\beta$-actin ratio is based on increased actin mRNA in the growth cone of 8-CPT-cAMP-stimulated Smn-deficient motoneurons (Fig. 8, G-N). Thus, elevated cAMP increases 
distal actin mRNA and protein levels in axons, leading to augmented $\mathrm{Ca}_{v} 2.2$ levels in growth cones and normalization of $\mathrm{Ca}^{2+}$ transient frequency. Subsequently, we tested whether this effect also rescues responsiveness to laminin-211/221 in the $S m n^{-/-}$; SMN2 motoneurons. As shown in Fig. $8(\mathrm{O}-\mathrm{R})$, axon length is shortened in $\mathrm{Smn}^{-/-}$; SMN2 neurons on laminin-211/221 when the cells are treated with 8-CPT-cAMP, indicating that the responsiveness to motor endplate-specific forms of laminin is restored by elevated cAMP levels.

\section{Discussion}

We have investigated the correlation between defective axon elongation and spontaneous excitability in motoneurons from a mouse model of SMA. We observed that the reduction of spontaneous $\mathrm{Ca}^{2+}$ transients in distal axons and growth cones is caused by defective $\mathrm{Ca}_{\mathrm{v}} 2.2$ accumulation and clustering in the axonal growth cones, thus influencing axon growth in the Smn-deficient motoneurons. These defects can be at least partially compensated by 8-CPT-cAMP treatment. Motoneuron disease in SMA, both in humans and mouse models, becomes apparent after motoneurons have made contact with skeletal muscle. In a mouse model of SMA type I, motoneuron loss is not enhanced during a critical period of development when motoneurons depend on trophic support from target tissues (Monani et al., 2000). Motoneuron numbers are normal at birth, but decrease at postnatal days 3-5. During this period, differentiation of motor endplates takes place, and we therefore investigated neurons that were cultured on motor endplate-specific forms of laminin (laminin-211/221). Previous papers have shown that neurite growth of motoneurons is impaired on this substrate (Porter et al., 1995). Furthermore, it has been shown that the $\beta 2$ chain in laminin-221 interacts with the pore-forming $\left(\mathrm{Ca}_{\mathrm{v}}\right)$ subunit of the $\mathrm{N}$ - and P/Q-type-specific VGCC $\left(\mathrm{Ca}_{\mathrm{v}} 2.2\right.$ and $\mathrm{Ca}_{\mathrm{v}} 2.1$; Nishimune et al., 2004), indicating that presynaptic differentiation is mediated through the direct interaction of laminin-221 with $\mathrm{Ca}_{\mathrm{v}} 2.2$ channels. Smn-deficient motoneurons exhibit a reduced accumulation of $\mathrm{Ca}_{\mathrm{v}} 2.2$ channels in growth cones. This finding correlates with reduced $\mathrm{Ca}^{2+}$ influx and reduced spontaneous electrical activity in this part of the neuron.

Gene knockout mice for the laminin $\beta 2$ chain $\left(\mathrm{Lamb2}^{-{ }^{--}}\right)$ or $\mathrm{Ca}_{\mathrm{v}} 2.1\left(\mathrm{Ca}_{v} 2.1^{-/-}\right)$exhibit strong synaptic maturation defects. Lamb2-deficient mice develop neuromuscular junction (NMJ) degeneration, which is characterized by disturbed active zones just after birth (Ino et al., 2001; Nishimune et al., 2004). $C a_{v} 2.2$ knockout mice do not show any signs of motoneuron disease, as the defect can most probably be compensated by $\mathrm{Ca}_{\mathrm{v}} 2.1$ expression. $\mathrm{Ca}_{\mathrm{v}} 2.1$-deficient mice develop normally until the third postnatal week (Jun et al., 1999). But from this time point on, as in $\mathrm{Lamb2}^{-/-}$mice, the NMJs degenerate and exhibit a decrease of active zone proteins (Nishimune et al., 2004; Fox et al., 2007). The delayed disease onset in $\mathrm{Ca}_{\mathrm{v}} 2.1$-deficient mice can be explained by a compensatory effect of residual $\mathrm{Ca}_{\mathrm{v}} 2.2$, which is substituted postnatally by $\mathrm{Ca}_{\mathrm{v}} 2.1$. Altogether, these data indicate that the $\beta 2$ chain interaction of laminin-221 with $\mathrm{Ca}_{\mathrm{v}} 2.1$ and $\mathrm{Ca}_{\mathrm{v}} 2.2$ supports postnatal development and maintenance of NMJs (Nishimune et al., 2004). Our data suggest that the reduced $\mathrm{Ca}_{\mathrm{v}} 2.2$ accumulation in the axonal growth cone protrusions of

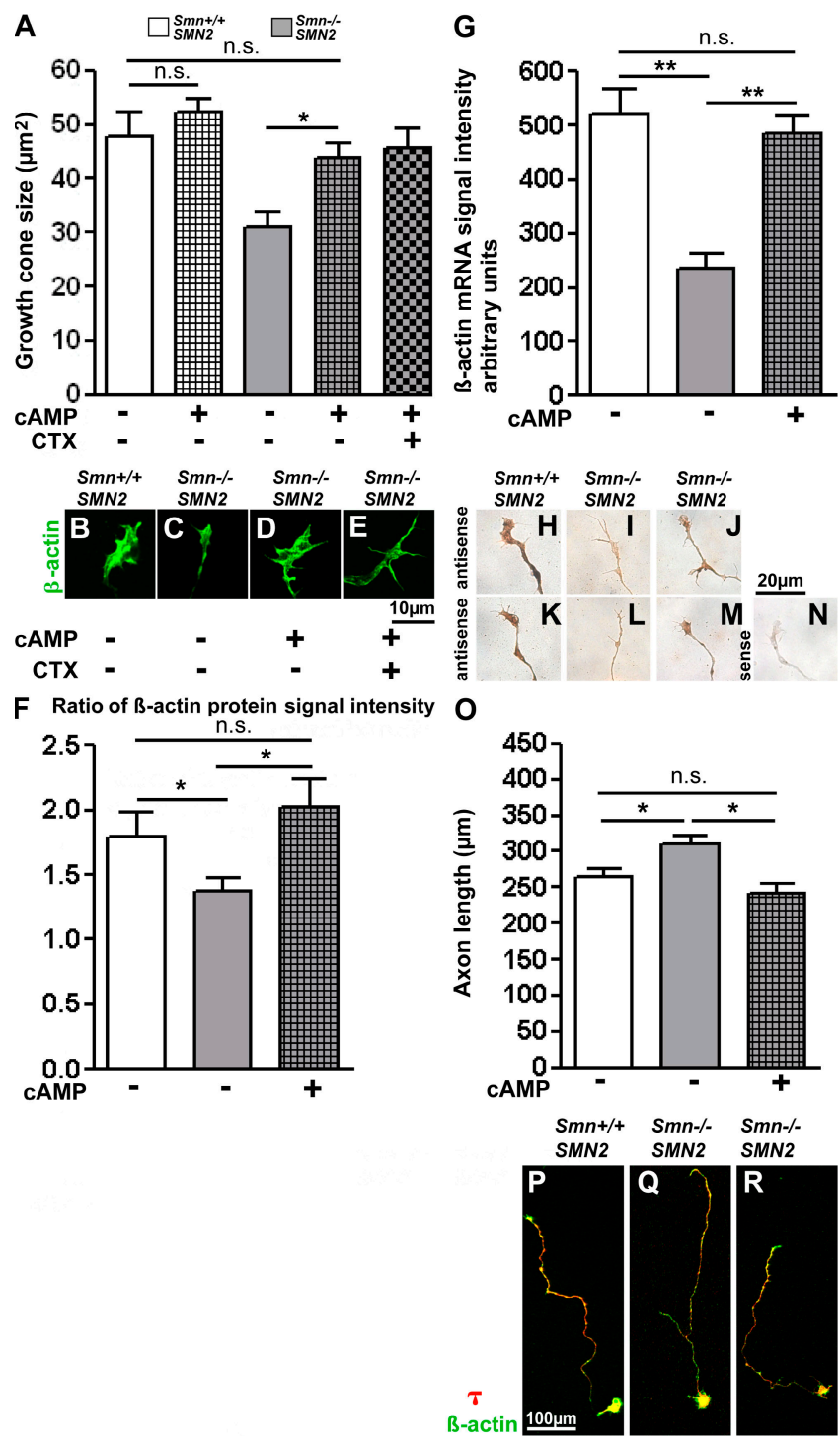

Figure 8. 8-CPT-cAMP restores axon elongation, growth cone size, and responses to laminin-211/221 in Smn ${ }^{-/-}$; SMN2 motoneurons. (A-E) The smaller growth cone size of 7-d-old Smn ${ }^{-1-}$; SMN2 motoneurons (A and C) is rescued by $100 \mu \mathrm{M}$ 8-CPT-cAMP (A [gray checkered bar] and D) and reaches the size of control motoneurons $(A, B$, and $D)$, also in the presence of CTX ( $A$ and $E ; n=30$ for each genotype with and without $100 \mu M$ 8-CPT-cAMP). (F) Ratio of $\beta$-actin content in the most distal part of the axon and the most proximal part of the axon. Smn ${ }^{-1-}$; SMN2 motor axons $(n=82)$ show reduced distal $\beta$-actin signal intensity in comparison to control cells $(n=78)$. 8-CPT-cAMP treatment of $\mathrm{Smn}^{-/-}$; SMN2 restores distal $\beta$-actin levels (checkered gray bar; $n=90$ ). (G-N) Analysis of actin mRNA levels in axonal growth cones by in situ hybridization in motoneurons from $\mathrm{Smn}^{-1-}$; SMN2 (G, I, and L; $n=30$ ), 8-CPT-cAMP-treated $S m n^{-1-} ; \operatorname{SMN} 2(G, J$, and $M ; n=32)$, and control embryos $(G, H$, and $K$; $n=30) .(G, J$, and M) 8-CPT-cAMP restores the actin mRNA deficit in axon terminals of $\mathrm{Smn}^{-1-}$; SMN2 motoneurons. (N) A sense actin probe was used as a negative control for the specificity of the actin probe. (O-R) 8-CPT-cAMP also restores the response of $\mathrm{Smn}^{-1-}$; SMN2 motor axons to laminin-21 1/221. Axon elongation after $7 \mathrm{~d}$ on laminin-21 1/221 in control $(\mathrm{P} ; n=141), \mathrm{Smn}^{-1-} ; \mathrm{SMN2}(\mathrm{Q} ; n=141)$ and 8-CPT-CAMPtreated $S m n^{-1-}$; SMN2 $(\mathrm{R} ; n=60)$ motoneurons. (O) Quantitative analysis of data. Results represent the mean \pm SEM of pooled data from three independent experiments. $n$, number of motoneurons that were scored in total from control, $\mathrm{Smn}^{-1-}$; SMN2, or $\mathrm{Smn}^{-1-}$; SMN2 embryos were treated with $100 \mu M$ 8-CPT-cAMP. *, P $<0.05 ;{ }^{* *}, \mathrm{P}<0.001$, tested by one-way ANOVA. 
Smn-deficient motoneurons is responsible for reduced axon elongation in cell culture and reduced responsiveness to synapsespecific laminin isoforms.

\section{Mislocalization of $\mathbf{N}$-type $\mathrm{Ca}^{2+}$ channels in Smn-deficient motoneurons on laminin-211/2e1 leads to local excitability defects at the growth cone}

In patients with SMA, extended neuromuscular latency to electrical stimulation is observed (Krajewska and HausmanowaPetrusewicz, 2002), pointing to defects in synaptic transmission at motor endplates. SMA is a dying-back disease in which the degeneration of motoneurons starts at the presynaptic part and proceeds backward to the cell body (Cifuentes-Diaz et al., 2002). Fly mutants lacking Smn show reduced excitatory postsynaptic currents and disorganized synaptic boutons, pointing to defects in synaptic function at NMJs (Chan et al., 2003). Such fly models provide further evidence for disturbed actin metabolism (Rajendra et al., 2007).

Target-derived signals play a critical role for presynaptic differentiation and maintenance during the period when synapses are eliminated and polysynaptic innervation of skeletal muscle fibers is removed (Nguyen and Lichtman, 1996). $\beta 2$-containing laminin isoforms act as signals for presynaptic differentiation (Son et al., 1999). The disturbed presynaptic synthesis of $\beta$-actin in Smn-deficient motoneurons interferes with VGCC translocalization to membrane clusters, which, in turn, could impair transmitter release from the axon terminals (Zhong and Zucker, 2004). Interestingly, other types of $\mathrm{Ca}^{2+}$ channels such as TRPC5 and 6 are not affected. These channels do not cluster on growth cone protrusions and are distributed more widespread over the growth cone. Moreover, double staining with Piccolo, a component of the presynaptic apparatus, revealed a severe defect of $\mathrm{Ca}_{\mathrm{v}} 2.2$ accumulation into active zone-like structures of Smn-deficient motoneurons.

Control motoneurons show reduced axon elongation on laminin-211/221 that correlates with increased $\mathrm{Ca}^{2+}$ spike frequency in axonal growth cones. The contribution of $\mathrm{Ca}_{\mathrm{v}} 2.2$ accumulation and subsequent enhanced frequency of $\mathrm{Ca}^{2+}$ transients to axon elongation on laminin-211/221 becomes evident by CTX treatment. $\mathrm{Ca}_{\mathrm{v}} 2.2$ inhibition restores axon elongation on laminin-221/211. The lack of response of Smn-deficient motoneurons to laminin-211/221 could be explained by a massive reduction of $\mathrm{Ca}^{2+}$ transients in the growth cone.

Collectively, we conclude that Smn-deficient motoneurons are not able to differentiate in response to synapse-specific laminins because of their incapability of accumulating $\mathrm{Ca}_{v} 2.2$ in axon terminals. Thus, defective $\mathrm{Ca}^{2+}$ channel accumulation could lead to dysfunction of the active zone (Nishimune et al., 2004), and this in turn could lead to disturbed neurotransmitter release and thus to degeneration of NMJs.

cAMP compensates for the morphological and functional defects in Smn-deficient motoneurons

We also found that 8-CPT-cAMP restored the defect in excitability in axon terminals of $\mathrm{Smn}^{-/}$; SMN2 motoneurons. 8-CPT-cAMP treatment enhances spontaneous $\mathrm{Ca}^{2+}$ influx into spinal motoneurons of Xenopus oocytes through VGCCs (Gorbunova and Spitzer, 2002). In addition, the ratio of cAMP to cGMP has been reported to regulate polarity in netrin-1-induced axon guidance in Xenopus spinal motoneurons (Nishiyama et al., 2003). The enhanced frequency of spontaneous $\mathrm{Ca}^{2+}$ transients in axonal growth cones of $\mathrm{Smn}^{-/-}$; SMN2 motoneurons correlates with increased $\mathrm{Ca}_{\mathrm{v}} 2.2$ accumulation in growth cones. It appears as if this defect is reversed by increased $\beta$-actin protein level in distal axons of $\mathrm{Smn}^{-/-}$; SMN2 motoneurons. Thus, our results with 8-CPTcAMP could guide the way to new therapeutic strategies for SMA.

\section{Materials and methods}

\section{Motoneuron culture}

The ventrolateral part of the lumbar spinal cord of E14 embryos was dissected and transferred to HBSS. After 15 min of treatment with $0.05 \%$ trypsin, cells were triturated and cultured after enrichment by panning with antibodies against the mouse p75 neurotrophin receptor (Abcam). Cells were plated at a density of 2,000 cells $/ \mathrm{cm}^{2}$ in 4 -well dishes (Greiner Bio-One) and cultured as described previously (Wiese et al., 1999). The culture dishes were precoated with polyornithine and laminin- 111 or laminin-211/221 (Invitrogen), respectively. $100 \mu$ M 8-CPT-cAMP (dissolved in HBSS; Calbiochem), $1 \mu M$ TTX (Sigma-Aldrich), and 1 or $0.3 \mu M$ CTX (Sigma-Aldrich), respectively, was added by changing the medium every second day.

\section{Forebrain neuronal precursor cell culture}

Precursor cells from the forebrain of 11.5-d-old mouse embryos were prepared, and neurospheres were cultured in neurobasal medium with $500 \mu \mathrm{M}$ glutamax (Invitrogen), $50 \mathrm{U} / \mathrm{ml}$ penicillin $\mathrm{G}$ sodium and $50 \mathrm{U} / \mathrm{ml}$ streptomycin sulfate (Invitrogen), B27 (1:50; Invitrogen), and $20 \mathrm{ng} / \mathrm{ml}$ EGF and bFGF (Cell Concepts).

For Western blot analysis, the neurospheres were plated at high density on $60-\mathrm{mm}$ dishes that had been coated with poly ornithine and laminin-1 11 . These cells were then grown for $72 \mathrm{~h}$.

\section{Antibodies used for immunocytochemistry}

Immunocytochemistry was performed as described previously (Rossoll et al., 2003). For analysis of membrane-exposed $\mathrm{N}$-type $\mathrm{Ca}^{2+}$ channels, we fixed the cells only for 2 min with 4\% PFA in $1 \times$ TBS without acetone. In addition, Tween 20 (Sigma-Aldrich) was omitted from all buffers for this set of experiments (Fig. 3, F-I). The following primary antibodies were used: rabbit polyclonal antibodies against tau at $1 \mu \mathrm{g} / \mathrm{ml}(1: 1,000$; Sigma-Aldrich), an N-type $\mathrm{Ca}^{2+}$ channel (1:200; Sigma-Aldrich), TRPC5 (1:200, SigmaAldrich), and TRPC6 (1:200, Chemicon), mouse monoclonal antibodies against $1 \mu \mathrm{g} / \mathrm{ml} \beta$-actin (Abcam), $1 \mu \mathrm{g} / \mathrm{ml}$ microtubule-associated protein 2 (Sigma-Aldrich), and $2 \mu \mathrm{g} / \mathrm{ml} \mathrm{Smn} \mathrm{(BD} \mathrm{Biosciences).} \mathrm{Cells} \mathrm{were} \mathrm{then}$ washed three times with $1 \times$ TBS-T $(20 \mathrm{mM}$ Tris-HCl, pH 7.6, $137 \mathrm{mM}$ $\mathrm{NaCl}$, and $0.1 \%$ Tween 20 ) and incubated for $1 \mathrm{~h}$ at room temperature with Cy2 (1:200)- and Cy3 (1:300)-conjugated secondary antibodies (Dianova). The Atto 647N-conjugated secondary antibody (Atto Technology) was used for STED microscopy. Confocal images were obtained either with a microscope (TCS 4D; Leica) with a $20 \times 0.5$ objective (PL FLUOTAR) or a microscope (SP2; Leica) with a 100× 1.4 oil-immersion objective $(\mathrm{HCX}$ PL APO CS), with identical settings for pinhole and voltage for control and Smn-deficient motoneurons. For high-resolution microscopy, a STED setup mounted to a microscope (SP5; Leica) with a $100 \times 1.4$ oil immersion objective was applied.

\section{Western blot analysis}

Forebrain neuronal precursor cells grown on laminin-111 for $72 \mathrm{~h}$ were collected from the dishes, and protein extraction for Western Blotting was performed as described previously (Rossoll et al., 2002). Primary antibodies, $1 \mu \mathrm{g} / \mathrm{ml}$ anti-mouse $\beta$-actin antibody (Abcam), $1 \mu \mathrm{g} / \mathrm{ml}$ anti-mouse $\beta$-III tubulin antibody (RDI), and $2 \mu \mathrm{g} / \mathrm{ml} \mathrm{Smn} \mathrm{lgG1} \mathrm{(BD} \mathrm{Biosciences)} \mathrm{were} \mathrm{used.}$

\section{Calcium imaging}

For $\mathrm{Ca}^{2+}$ imaging analysis, cultured motoneurons were grown on glass coverslips. After gently washing in phenol red-free HBSS and permeabilization with $0.25 \%$ pluronic F-127 (Sigma-Aldrich) over $5 \mathrm{~min}$, cells were 
loaded with $2 \mu$ M FURA-2 AM (Invitrogen) at $37^{\circ} \mathrm{C}$ for $45 \mathrm{~min}$ in $\mathrm{Ca}^{2+}$ and $\mathrm{Mg}^{2+}$ containing HBSS. After washing, coverslips were mounted on a heated microscope stage $\left(37^{\circ} \mathrm{C}\right)$ and constantly superfused with $\mathrm{Ca}^{2+} / \mathrm{Mg}^{2+}-\mathrm{HBSS}$ under linear flow conditions.

Measurements were performed by dual-excitation and dual-emission ratio imaging using a microscope fluorescence measurement workstation (Polychrome II; TILL Photonics). Motoneurons were alternately exposed to monochromatic light of 340 and $380 \mathrm{~nm}$, and emission was measured at $512 \mathrm{~nm}$. Real-time microscope imaging was performed using a microscope (Axiovert S100TV; Carl Zeiss Microlmaging, Inc.) equipped for epifluorescence with a dichroid mirror, a $100 \times 1.3$ oil-immersion objective (Fluor; Carl Zeiss Microlmaging, Inc.), and a charge-coupled device camera (IMAGO; TILL Photonics).

Images were acquired at a frequency of $1 \mathrm{~Hz}$ and exposure time was $10 \mathrm{~ms}$. The measurements in proximal axons were taken at a distance of 10-30 $\mathrm{m}$ from the cell body. Spontaneous $\mathrm{Ca}^{2+}$ transients (340:380) were recorded separately in cell bodies, dendrites, axons, and growth cones over a time period of $7.5 \mathrm{~min}$.

Permeabilizing the motoneurons with $20 \mu \mathrm{M}$ digitonin allowed background signal detection after cytosolic dye release for background correction. Cells were constantly superfused with $\mathrm{Ca}^{2+} / \mathrm{Mg}^{2+}-\mathrm{HBSS}$ over the registration time.

\section{In situ hybridization}

Hybridization solution containing $3^{\prime}$ biotinylated sense or antisense actin or N-type $\mathrm{Ca}^{2+}$ channel oligonucleotides $(200 \mathrm{ng} / \mathrm{ml}$; GeneDetect) was applied to the coverslips. Hybridization was performed as described previously (Rossoll et al., 2003). Images were acquired using a microscope (Axiophot; Carl Zeiss Microlmaging, Inc.) equipped with a charge-coupled device camera using Axioplan 2 software (Carl Zeiss Microlmaging, Inc.).

\section{RT-PCR from neuronal stem cells}

Total RNA from neuronal precursor cells was extracted by Trizol (Invitrogen) according to the manufacturer's protocol, and $1 \mu \mathrm{g}$ of total RNA was used for cDNA amplification. Amplification of the SMN2 cDNA was performed with Ex $5 f$ (5'-CCACTTACTATCATGCT-3') and Ex $8 r$ (5'-CTACAACACCCTTCTCACAG- $3^{\prime}$ ) primers under the following PCR conditions: 3 min at $94^{\circ} \mathrm{C}$ ( 1 cycle), $30 \mathrm{~s}$ at $94^{\circ} \mathrm{C}, 30 \mathrm{~s}$ at $56^{\circ} \mathrm{C}, 45 \mathrm{~s}$ at $72^{\circ} \mathrm{C}$ (30 cycles), and 5 min at $72^{\circ} \mathrm{C}$ (1 cycle).

\section{Data analysis}

Axons of motoneurons were identified by their length as processes that are at least two times longer than dendrites. Only the longest axonal branches were measured. Cultures obtained from mutant and control embryos from different litters were analyzed under a microscope (TCS4D; Leica), and axon length was measured from pictures using image software (Scion Corporation).

For the quantification of $\beta$-actin and $\mathrm{N}$-type $\mathrm{Ca}^{2+}$ channel distribution within the different cellular compartments, the staining intensity in the cell body, the proximal and the distal third of the axon, and the growth cone were analyzed with AIDA software (Raytest). Background intensity was measured for every single picture. The intensity for $\beta$-actin and $\mathrm{N}$-type $\mathrm{Ca}^{2+}$ channels was measured as arbitrary units per area, based on quantum levels per pixel, according to the manufacturer's instructions.

For STED microscopy, LAS AF acquisition software (modified by Leica) was used. The deconvolution processing was performed with Inspector (Max-Planck Institute).

The final processing of all images was performed with Photoshop 7.0 (Adobe) and Illustrator 10 (Adobe). Linear contrast enhancement was applied to Figs. $1(E-N), 4(B-E)$, and $8(P-R)$, and all individual panels contained in these figures were treated similarly.

Values from at least three independent experiments were pooled and the results were expressed as the mean \pm SEM. Statistical significance of differences were assessed by one-way analysis of variance (ANOVA) and Bonferroni after testing using Prism software (GraphPad).

\section{Online supplemental material}

Fig. S1 shows that $\mathrm{Ca}^{2+}$ transient frequency is reduced by TTX and CTX in cultured motoneurons from 14-d-old mouse embryos. Fig. S2 shows colocalization of $\mathrm{Ca}_{\mathrm{v}} 2.2$ and the presynaptic protein Piccolo in protrusions of axonal growth cones in control and $\mathrm{Smn}^{-1-}$; SMN2 motoneurons. Fig. S3 shows distribution and semiquantitative analysis of TRPC 5 and 6 immunoreactivity in the growth cones of control and Smn-deficient motoneurons. Fig. S4 shows that 8-CPT-cAMP stimulates SMN2 and Smn transcription and increases Smn protein levels in Smn-deficient forebrain neuronal precursor cells. Online supplemental material is available at http://www.jcb .org/cgi/content/full/200703187/DC1.
We thank Christine Schneider for skillful technical assistance and Manfred Heckmann and Stefan Sigrist for many helpful suggestions and comments on the manuscript. We also thank Markus Dyba from Leica for support in STED microscopy

This work was supported by grants from the Spinal Muscular Atrophy Foundation, the Deutsche Forschungsgemeinschaft (SFB 581, TP B 1), and the Herrmann and Lilly Schilling-Stiftung.

Submitted: 28 March 2007

Accepted: 11 September 2007

\section{References}

Boillee, S., V.C. Vande, and D.W. Cleveland. 2006. ALS: a disease of motor neurons and their nonneuronal neighbors. Neuron. 52:39-59.

Bruijn, L.I., T.M.Miller, and D.W.Cleveland. 2004. Unraveling the mechanisms involved in motor neuron degeneration in ALS. Anпи. Rev. Neurosci. 27:723-49.

Chan, Y.B., I. Miguel-Aliaga, C. Franks, N. Thomas, B. Trulzsch, D.B. Sattelle, K.E. Davies, and H.M. van den Heuvel. 2003. Neuromuscular defects in a Drosophila survival motor neuron gene mutant. Hum. Mol. Genet. 12:1367-1376.

Ciccolini, F., T.J. Collins, J. Sudhoelter, P. Lipp, M.J. Berridge, and M.D. Bootman. 2003. Local and global spontaneous calcium events regulate neurite outgrowth and onset of GABAergic phenotype during neural precursor differentiation. J. Neurosci. 23:103-111.

Cifuentes-Diaz, C., S. Nicole, M.E. Velasco, C. Borra-Cebrian, C. Panozzo, T. Frugier, G. Millet, N. Roblot, V. Joshi, and J. Melki. 2002. Neurofilament accumulation at the motor endplate and lack of axonal sprouting in a spinal muscular atrophy mouse model. Hum. Mol. Genet. 11:1439-1447.

Crawford, T.O., and C.A. Pardo. 1996. The neurobiology of childhood spinal muscular atrophy. Neurobiol. Dis. 3:97-110.

Dyba, M., and S.W. Hell. 2003. Photostability of a fluorescent marker under pulsed excited-state depletion through stimulated emission. Appl. Opt. 42:5123-5129.

Fox, M.A., J.R. Sanes, D.B. Borza, V.P. Eswarakumar, R. Fässler, B.G. Hudson, S.W. John, Y. Ninomiya, V. Pedchenko, S.L. Pfaff, et al. 2007. Distinct target-derived signals organize formation, maturation, and maintenance of motor nerve terminals. Cell. 129:179-193.

Gorbunova, Y.V., and N.C. Spitzer. 2002. Dynamic interactions of cyclic AMP transients and spontaneous $\mathrm{Ca}(2+)$ spikes. Nature. 418:93-96.

Greka, A., B. Navarro, E. Oancea, A. Duggan, and D.E. Clapham. 2003. TRPC5 is a regulator of hippocampal neurite length and growth cone morphology. Nat. Neurosci. 6:837-845.

Gu, X., and N.C. Spitzer. 1995. Distinct aspects of neuronal differentiation encoded by frequency of spontaneous $\mathrm{Ca} 2+$ transients. Nature. 375:784-787.

Gu, X., E.C. Olson, and N.C. Spitzer. 1994. Spontaneous neuronal calcium spikes and waves during early differentiation. J. Neurosci. 14:6325-6335.

Iannaccone, S.T., S.A. Smith, and L.R. Simard. 2004. Spinal muscular atrophy. Curr. Neurol. Neurosci. Rep. 4:74-80.

Ino, M., T. Yoshinaga, M. Wakamori, N. Miyamoto, E. Takahashi, J. Sonoda, T. Kagaya, T. Oki, T. Nagasu, Y. Nishizawa, et al. 2001. Functional disorders of the sympathetic nervous system in mice lacking the alpha 1B subunit (Cav 2.2) of N-type calcium channels. Proc. Natl. Acad. Sci. USA. 98:5323-5328.

Jia, Y., J. Zhou, Y. Tai, and Y. Wang. 2007. TRPC channels promote cerebellar granule neuron survival. Nat. Neurosci. 10:559-567.

Jun, K., E.S. Piedras-Renteria, S.M. Smith, D.B. Wheeler, S.B. Lee, T.G. Lee, H. Chin, M.E. Adams, R.H. Scheller, R.W. Tsien, and H.S. Shin. 1999. Ablation of P/Q-type $\mathrm{Ca}(2+)$ channel currents, altered synaptic transmission, and progressive ataxia in mice lacking the alpha(1A)-subunit. Proc. Natl. Acad. Sci. USA. 96:15245-15250.

Kittel, R.J., C. Wichmann, T.M. Rasse, W. Fouquet, M. Schmidt, A. Schmid, D.A. Wagh, C. Pawlu, R.R. Kellner, K.I. Willig, et al. 2006. Bruchpilot promotes active zone assembly, $\mathrm{Ca} 2+$ channel clustering, and vesicle release. Science. 312:1051-1054.

Krajewska, G., and I. Hausmanowa-Petrusewicz. 2002. Abnormal nerve conduction velocity as a marker of immaturity in childhood muscle spinal atrophy. Folia Neuropathol. 40:67-74.

Lefebvre, S., L. Burglen, S. Reboullet, O. Clermont, P. Burlet, L. Viollet, B. Benichou, C. Cruaud, P. Millasseau, M. Zeviani, et al. 1995. Identification and characterization of a spinal muscular atrophy-determining gene. Cell. 80:155-165.

Li, Y., Y.C. Jia, K. Cui, N. Li, Z.Y. Zheng, Y.Z. Wang, and X.B. Yuan. 2005. Essential role of TRPC channels in the guidance of nerve growth cones by brain-derived neurotrophic factor. Nature. 434:894-898. 
Lorson, C.L., E. Hahnen, E.J. Androphy, and B. Wirth. 1999. A single nucleotide in the SMN gene regulates splicing and is responsible for spinal muscular atrophy. Proc. Natl. Acad. Sci. USA. 96:6307-6311.

Majumder, S., S. Varadharaj, K. Ghoshal, U. Monani, A.H. Burghes, and S.T. Jacob. 2004. Identification of a novel cyclic AMP-response element (CRE-II) and the role of CREB-1 in the cAMP-induced expression of the survival motor neuron (SMN) gene. J. Biol. Chem. 279:14803-14811.

Meister, G., D. Buhler, R. Pillai, F. Lottspeich, and U. Fischer. 2001. A multiprotein complex mediates the ATP-dependent assembly of spliceosomal U snRNPs. Nat. Cell Biol. 3:945-949.

Monani, U.R. 2005. Spinal muscular atrophy: a deficiency in a ubiquitous protein; a motor neuron-specific disease. Neuron. 48:885-896.

Monani, U.R., C.L. Lorson, D.W. Parsons, T.W. Prior, E.J. Androphy, A.H. Burghes, and J.D. McPherson. 1999. A single nucleotide difference that alters splicing patterns distinguishes the SMA gene SMN1 from the copy gene SMN2. Hum. Mol. Genet. 8:1177-1183.

Monani, U.R., M. Sendtner, D.D. Coovert, D.W. Parsons, C. Andreassi, T.T. Le, S. Jablonka, B. Schrank, W. Rossol, T.W. Prior, et al. 2000. The human centromeric survival motor neuron gene (SMN2) rescues embryonic lethality in $\operatorname{Smn}(-/-)$ mice and results in a mouse with spinal muscular atrophy. Hum. Mol. Genet. 9:333-339.

Nguyen, Q.T., and J.W. Lichtman. 1996. Mechanism of synapse disassembly at the developing neuromuscular junction. Curr. Opin. Neurobiol. 6:104-112.

Nishimune, H., J.R. Sanes, and S.S. Carlson. 2004. A synaptic laminin-calcium channel interaction organizes active zones in motor nerve terminals. Nature. 432:580-587.

Nishiyama, M., A. Hoshino, L. Tsai, J.R. Henley, Y. Goshima, M. TessierLavigne, M.M. Poo, and K. Hong. 2003. Cyclic AMP/GMP-dependent modulation of $\mathrm{Ca} 2+$ channels sets the polarity of nerve growth-cone turning. Nature. 423:990-995.

Pasinelli, P., and R.H. Brown. 2006. Molecular biology of amyotrophic lateral sclerosis: insights from genetics. Nat. Rev. Neurosci. 7:710-723.

Pellizzoni, L., J. Yong, and G. Dreyfuss. 2002. Essential role for the SMN complex in the specificity of snRNP assembly. Science. 298:1775-1779.

Porter, B.E., J. Weis, and J.R. Sanes. 1995. A motoneuron-selective stop signal in the synaptic protein S-laminin. Neuron. 14:549-559.

Rajendra, T.K., G.B. Gonsalvez, M.P. Walker, K.B. Shpargel, H.K. Salz, and A.G Matera. 2007. A Drosophila melanogaster model of spinal muscular atrophy reveals a function for SMN in striated muscle. J. Cell Biol. 176:831-841.

Rossoll, W., A.K. Kroning, U.M. Ohndorf, C. Steegborn, S. Jablonka, and M. Sendtner. 2002. Specific interaction of Smn, the spinal muscular atrophy determining gene product, with hnRNP-R and gry-rbp/hnRNP-Q: a role for Smn in RNA processing in motor axons? Hum. Mol. Genet. 11:93-105.

Rossoll, W., S. Jablonka, C. Andreassi, A.K. Kroning, K. Karle, U.R. Monani, and M. Sendtner. 2003. Smn, the spinal muscular atrophy-determining gene product, modulates axon growth and localization of $\beta$-actin mRNA in growth cones of motoneurons. J. Cell Biol. 163:801-812.

Schrank, B., R. Gotz, J.M. Gunnersen, J.M. Ure, K.V. Toyka, A.G. Smith, and M. Sendtner. 1997. Inactivation of the survival motor neuron gene, a candidate gene for human spinal muscular atrophy, leads to massive cell death in early mouse embryos. Proc. Natl. Acad. Sci. USA. 94:9920-9925.

Son, Y.J., B.L. Patton, and J.R. Sanes. 1999. Induction of presynaptic differentiation in cultured neurons by extracellular matrix components. Eur. J. Neurosci. 11:3457-3467.

Spafford, J.D., and G.W. Zamponi. 2003. Functional interactions between presynaptic calcium channels and the neurotransmitter release machinery. Curr. Opin. Neurobiol. 13:308-314.

Spitzer, N.C. 2002. Activity-dependent neuronal differentiation prior to synapse formation: the functions of calcium transients. J. Physiol. (Paris). 96:73-80.

Spitzer, N.C., N.J. Lautermilch, R.D. Smith, and T.M. Gomez. 2000. Coding of neuronal differentiation by calcium transients. Bioessays. 22:811-817.

Swash, M., and J. Desai. 2000. Motor neuron disease: classification and nomenclature. Amyotroph. Lateral Scler. Other Motor Neuron Disord. 1:105-112.

Talbot, K., and K.E. Davies. 2001. Spinal muscular atrophy. Semin. Neurol. 21:189-197.

Urbano, F.J., M.D. Rosato-Siri, and O.D. Uchitel. 2002. Calcium channels involved in neurotransmitter release at adult, neonatal and P/Q-type deficient neuromuscular junctions (Review). Mol. Membr. Biol. 19:293-300.

Urushitani, M., A. Sik, T. Sakurai, N. Nukina, R. Takahashi, and J.P. Julien. 2006. Chromogranin-mediated secretion of mutant superoxide dismutase proteins linked to amyotrophic lateral sclerosis. Nat. Neurosci. 9:108-118.

Wiese, S., F. Metzger, B. Holtmann, and M. Sendtner. 1999. The role of p75NTR in modulating neurotrophin survival effects in developing motoneurons. Eur. J. Neurosci. 11:1668-1676.
Willig, K.I., S.O. Rizzoli, V. Westphal, R. Jahn, and S.W. Hell. 2006. STED microscopy reveals that synaptotagmin remains clustered after synaptic vesicle exocytosis. Nature. 440:935-939.

Winkler, C., C. Eggert, D. Gradl, G. Meister, M. Giegerich, D. Wedlich, B. Laggerbauer, and U. Fischer. 2005. Reduced U snRNP assembly causes motor axon degeneration in an animal model for spinal muscular atrophy. Genes Dev. 19:2320-2330.

Zhong, N., and R.S. Zucker. 2004. Roles of $\mathrm{Ca} 2+$, hyperpolarization and cyclic nucleotide-activated channel activation, and actin in temporal synaptic tagging. J. Neurosci. 24:4205-4212.

Ziskind-Conhaim, L. 1988. Electrical properties of motoneurons in the spinal cord of rat embryos. Dev. Biol. 128:21-29. 